
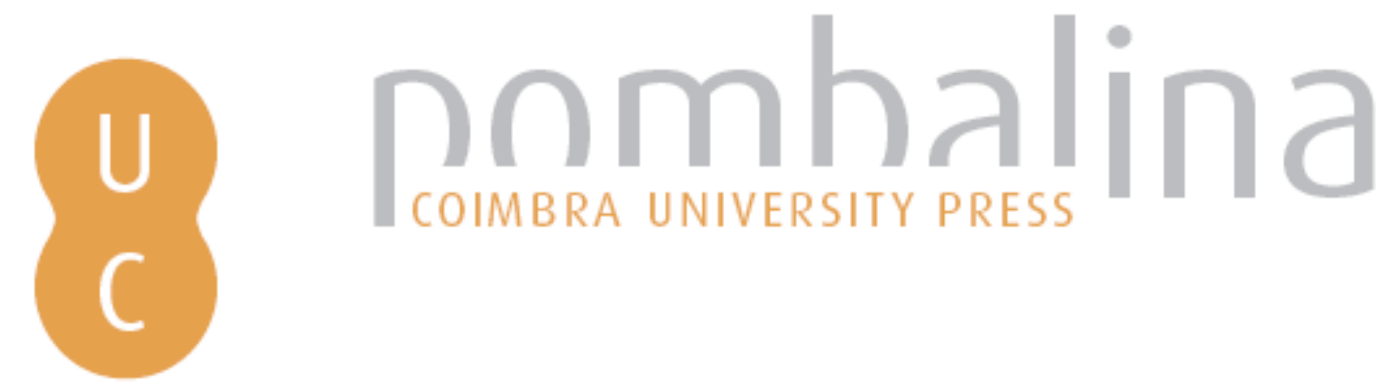

\title{
Cosmopolitan Trends in the Arts of Ptolemaic Alexandria
}
Autor(es):
Haggag, Mona
Edições Afrontamento; CITCEM - Centro de Investigação
Publicado por: Transdisciplinar "Cultura, Espaço e Memória»; Centro de Estudos Clássicos e Humanísticos; Alexandria University; Imprensa da Universidade de Coimbra
$\begin{array}{ll}\text { URL } & \text { URI:http://hdl.handle.net/10316.2/36161 } \\ \text { persistente: } & \text { DOI:http://dx.doi.org/10.14195/978-989-26-0966-9_6 }\end{array}$
Accessed : $\quad$ 26-Apr-2023 14:20:37

A navegação consulta e descarregamento dos títulos inseridos nas Bibliotecas Digitais UC Digitalis, UC Pombalina e UC Impactum, pressupõem a aceitação plena e sem reservas dos Termos e Condições de Uso destas Bibliotecas Digitais, disponíveis em https://digitalis.uc.pt/pt-pt/termos.

Conforme exposto nos referidos Termos e Condições de Uso, o descarregamento de títulos de acesso restrito requer uma licença válida de autorização devendo o utilizador aceder ao(s) documento(s) a partir de um endereço de IP da instituição detentora da supramencionada licença.

Ao utilizador é apenas permitido o descarregamento para uso pessoal, pelo que o emprego do(s) título(s) descarregado(s) para outro fim, designadamente comercial, carece de autorização do respetivo autor ou editor da obra.

Na medida em que todas as obras da UC Digitalis se encontram protegidas pelo Código do Direito de Autor e Direitos Conexos e demais legislação aplicável, toda a cópia, parcial ou total, deste documento, nos casos em que é legalmente admitida, deverá conter ou fazer-se acompanhar por este aviso.

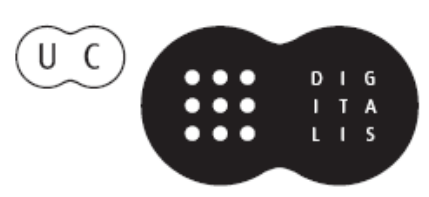




\title{
COSMOPOLITAN TRENDS \\ IN THE ARTS OF PTOLEMAIC ALEXANDRIA
}

\author{
MONA HAGGAG
}

University of Alexandria. Archaeological Society of Alexandria

\begin{abstract}
Among all the Alexandrias, Alexandria of Egypt enjoyed the quality of universality. Despite the glory achieved by the city for more than a thousand years, only a few monuments from that city remain, which do not match the glory and the greatness of its past. Nevertheless these remains are expressive of diversity in different fields. In the light of recent archaeological discoveries, we realize that fusion in Alexandrian art began with the time of the first two Ptolemies. One would tend to think of Ptolemaic Alexandria as a city that incorporated Egyptian and Greek traditions in both physical and cultural aspects of its life. New artistic motives were created to express the intellectual and artistic richness of the different cultures that resided in Alexandria and were influenced by the city's heterogeneous and cosmopolitan society. This paper is tracking the archaeological evidence on the universal trends in ancient Alexandrian art through an investigation of some monuments.
\end{abstract}

Although Alexander the Great had never saw a single building in the new city which he ordered to be founded on the northern coast of Egypt, the building project was undertaken by the first two Ptolemies who succeeded the great conqueror on the throne of Egypt. Few decades after its construction, Alexandria proved to have become the metropolis of the Mediterranean. Due to its harbours and lighthouse, it played the role of a main trading centre and enjoyed a flourishing economy. The Ptolemies tended to make their capital city a place of attraction not only for merchants and businessmen but also for men of letters and 
thoughts as well as skilled artists. Various ethnic groups from the then known world flocked into the city seeking its luxurious life and its new intellectual and artistic attractions. The Alexandrian scholarship through the Museum and its universal library had extended its influence on the mentality of the Alexandrian society as well as the other societies throughout the Hellenistic world. Such a society that hosted people of different races, religious ideas, languages, traditions and historical backgrounds was able to contribute to the human attitudes of life. Those factors had no doubt given Alexandrian life a concept of cosmopolitanism.

Tangible evidences of such an impressively leading society are unfortunately very few and do not match the glory and the greatness of Alexandria's past. Yet, the available archaeological remains can give us an idea about the nature of the artistic production of Ptolemaic Alexandria.

The main essences of Alexandria's multiculturalism, according to the majority of its inhabitants, were the two prominent civilizations of Egypt and Greece. Part of the Ptolemaic interior policy was to bridge the gap between the two traditions. To achieve this target, a new architectural and iconographic program was created. Such a program would have combined elements that can be accepted and appreciated by both races.

For the Ptolemies, Alexandria was intended to be a Greek city in its administrative, political and physical forms. They patronized the building of Greek temples for Greek deities and for themselves after the establishment of their dynastic ruler cult ${ }^{1}$. Greek artists were among those who, encouraged by the rulers, migrated to Alexandria and began to produce their arts. Temples were built on the conventional Greek style using, not marble, but the available building material which were mainly limestone from Mex quarries (a suburb of Alexandria) or Granite from Aswan. The recently discovered limestone Boubasteion ${ }^{2}$ which is fully Greek in its architectural design and the artifacts it yielded, and the famous Serapeum at the district of Rhacotis are testimonies of Greek architecture and taste. The majority of the architectural remains in both materials that are found sporadically in the city indicate the existence of the three main architectural orders known in Greek architecture.

On the other hand, outside Alexandria and the other Greek cities, the Ptolemies subsidized the building of new temples dedicated to the Egyptian gods in the typical Pharaonic architectural style. They also patronized the restoration, enlargement and the embellishment of some old temples in different cities of the Nile valley ${ }^{3}$. To declare their loyalty to

\footnotetext{
${ }^{1}$ FRASER, 1972: I, 213-46.

${ }^{2}$ This temple has been partially uncovered in a rescue excavation by the Egyptian Supreme Council of Antiquities inside the premises of the Central Security Forces of Alexandria in Ismail Fahmy Street at Kom El-Dikka, to the south of Foad Street, an area which was part of the ancient city's downtown. Excavation reports has not yet been published but the foundation deposits, coins and the style of the uncovered marble and terracotta statuettes (more than 500 pieces) date the temple to the reign of Ptolemy III Euergetes.

${ }^{3}$ Examples are at Dendera, Edfu, Kom Ombo, Philae and others. For a full discussion of the Ptolemaic policy towards the Egyptian temples and priests see: HÖLBL, 2001: $77 \mathrm{ff}$.
} 
the Egyptian pantheon, they themselves were depicted on the walls of those temples as Pharaohs offering and paying hommage to the deities of the temples in a manner similar to what the native kings were used to.

The duality can clearly be attested in the royal portraits not only in temple reliefs but also in free standing monumental sculptures ${ }^{4}$. The basalt bust of Ptolemy I in the British Museum is one good example ${ }^{5}$. It shows the king wearing the Pharaonic nemes-headdress and the uraeus. The wide smile, the fleshy facial features and the highly raised ears are characteristics of the portraits of Pharaohs of the 30th Dynasty. In spite of the Egyptian idealistic facial features, the naturalistic finishing of the surface and the raised eyebrows indicate a Ptolemaic dating. The Louvre has one striking example of a Greek style portrait of the same king ${ }^{6}$. The marble head is slightly turned to the left with emphasized neck bones. The rendering of the facial features indicates the king's mature age. The round eyes, articulated lips and the large protruding chin are similar to the coin portraits of Soter ${ }^{7}$. The twin granite statues of Philadelphus and Arsinoe II in the Vatican Museum ${ }^{8}$, identified only by inscriptions, show how obscure and general the representation of the royal couple is. The fleshy faces, single-arc eyebrows, full lips and the idealistic smile, are features typical to the royal portraits of the 30th Dynasty ${ }^{9}$. The entire execution of the two statues is pure Egyptian; garments are the traditional Pharaonic shendyt-kilt and the transparent tight female dress. The frontal posture of the body with the advanced left leg and the clenched hands holding something in the fist, part of the dress as in the Vatican Arsinoe or ankh-sign as in the basalt statue of Cleopatra VII in the Hermitage Museum ${ }^{10}$, are direct indications for their Egyptian style free from any Greek element. The queen wears the Egyptian wig adorned with a double uraeus, an Egyptian attribute referring to the queen's epithet as mistress of the Two Lands. On the faïence oinochoe decorated in relief known as the queens' vases $^{11}$, and on the coins of Arsinoe II which represent the queen in a pure Greek style, this double uraeus has been translated into a double cornucopia, a Ptolemaic invention which

\footnotetext{
${ }^{4}$ It is worthy of mentioning here that the portraits of the Egyptian high officials and priests followed the same development of the Egyptian style royal portraiture. STANWICK, 2002: 67.

${ }^{5}$ Inv. EA 1641. BUDGE, 1914: 23, pl. 52; ASHTON, 2001a: 40-41, no. 3.

${ }^{6}$ Musée du Louvre Ma 849: KYRIELEIS, 1975: 12, 41, 126, 165, A 1, pl. 2; SMITH, 1988: 90, 111, 164, no. 46, pl. 34, 1-3.

${ }^{7}$ For other examples of pure Greek style Ptolemaic portraits see: ASHTON, 2001b: 8-11; STANWICK, 2002: 221-36, nos. $213-82$.

${ }^{8}$ Vatican Museo Gregoriano Egizio, respectively nos. 22681. 22682. JOSEPHSON, 1997a: 43-44, pl. 13c; ARNOLD, 1999: 342, no. 72; STANWICK, 2002: 66-67, nos. A3, A4.

${ }_{9}$ JOSEPHSON, 1997a: 8, 13, 26, 35, 43, 1. 3b.

${ }^{10}$ St. Petersburg, Hermitage Museum, inv. 3936. identified as Arsinoe II by BOTHMER 1960: 192; This identification proved to be incorrect because of the triple uraeus, exclusively an attribute of the last queen in the dynasty of the Lagids as well as the down turned corners of the mouth and narrow eyes which are typical to Cleopatra's portraits on her coins, see: ASHTON, 2001a: 160-61, no.160.

11 THOMPSON, 1973: passim; ASHTON, 2003: passim.

12 The other queen who carried the double cornucopia in her portraits was Cleopatra VII who was known for her attempt to imitate Arsinoe II. The basalt statue in the Hermitage Museum is one clear example. See supra n. 10.
} 
became an exclusive attribute of Arsinoe $\mathrm{II}^{12}$. Other Pharaonic regalia are invariably represented in the Egyptian style portraits of the Ptolemies such as the uraeus, the double crown of Upper and Lower Egypt, the back pillars sometimes inscribed in hieroglyphs. One would be sure that an Egyptian native sculptor was in charge for the execution of such statues ${ }^{13}$. The majestic appearance and the divine atmosphere following the native Egyptian norms and the understanding of the Egyptian religious ideology emphasizes the legitimacy of the new rulers and expresses continuity in Dynastic kingship.

The duality of Ptolemaic official artistic styles, Greek for Alexandria and the other Greek cities in Egypt, namely Naucratis and Ptolemaiss, and Egyptian for the rest of the country is supposed to have been dominating Ptolemaic arts at least up till year 217 B.C. ${ }^{14}$. In this year the Raphia battle took place and the Egyptian fighters proved to have been strong enough to achieve victory ${ }^{15}$. This seemed to have been a turning point in the Ptolemaic policy towards the Egyptians. Intermarriage between the Greeks and the Egyptians

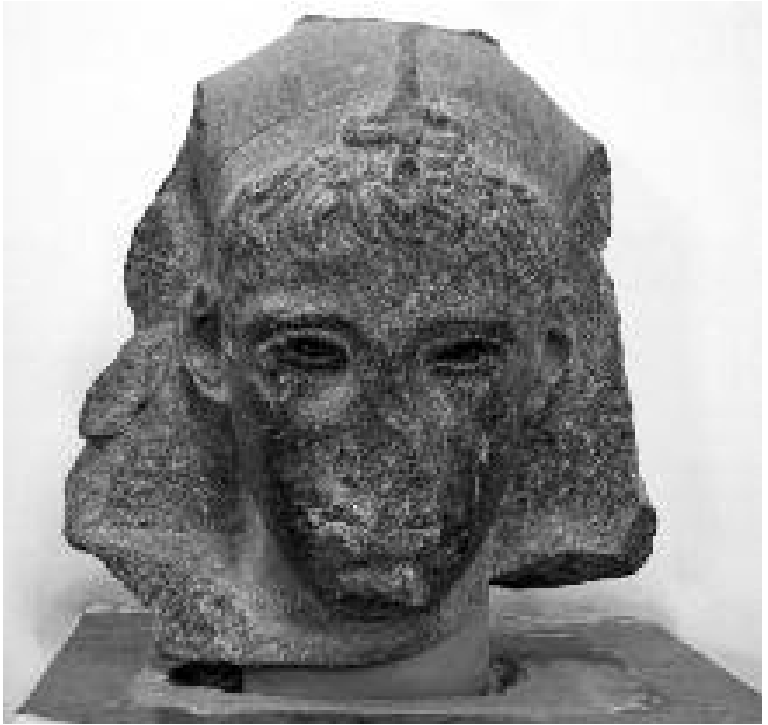

Fig. 1: Head of Ptolemy VI, Greco-Roman Museum of Alexandria (photo by the author). had increasingly been accepted. The offspring of such a social change was a new generation whose artists had the aptitude of mingling different elements from both traditions. Hence a new style emerged based on the Egyptian approach incorporated with Greek ideas. Greek hair and faces with individualizing features coherent to the subject's personality are the main characteristics of the new style.

Examples of this mixed style portraits are very numerous and are dated from the reign of Ptolemy IV to the end of the Ptolemaic rule. Their geographical distribution is so wide that they cover the entire country including Alexandria. The collection of the

\footnotetext{
${ }^{13}$ For other examples of pure Egyptian style portraits see: BOTHMER, 1960: passim; ASHTON, 2001a: 42-43, no. 5; 54-55, no. 20; 56, no. 22; ASHTON, 2001b: 84-88, nos. 5-11; STANWICK, 2002: nos. A3-A42.

14 The study of Ibrahim Noshy published in 1937 has been one of the first studies to discuss this duality. Noshy insisted on the idea that the Greek and Egyptian styles went in two parallel lines with no interfusion or mingling between the two traditions: NOSHY, 1937: passim.

${ }^{15}$ ROSTOVTZEFF, 1955: 559-61; FRASER, 1972: I, 60-61.

${ }^{16}$ Inv. 3357, from Canopus, a suburb of Alexandria.
} 
Greco-Roman Museum of Alexandria has a grey granite head (Fig. 1) ${ }^{16}$ attributed to Ptolemy VI ${ }^{17}$. The head was part of a colossal statue supported by a back pillar in the Pharaonic style which shows the king wearing the nemes-headdress with a uraeus. The facial features are similar to Philometor's coins. The hair, unknown in the native Pharaonic iconography, is rendered in a naturalistic way over the forehead. The eyes which were inlaid (inlay is now missing) have the almond shape which is sometimes called «the Ptolemaic eyes» because of resemblance with many other portraits of members of the Lagid family.

This sequence of duality was evident until the last two decades of the past century ${ }^{18}$ when a series of underwater discoveries took place by two great French expeditions jointly with the $\mathrm{SCA}^{19}$, in areas around the citadel of Qaitbay, the coasts of the former Pharos Island and in the Eastern harbour and the suburb towns of Canopos and Herakleion. These two extensive excavations resulted in the discovery of hundreds of granite blocks from huge buildings and a considerable number of Greco-Egyptian style Ptolemaic royal portraits which had once stood at the entrance of the eastern harbour of Alexandria. Studies of the fruits of these discoveries led to a dramatic change in two previously established ideas. The first is related to the period when the shift from the purely Egyptian representations of the Ptolemies to the new trend of incorporating Greek elements took place. The second is the idea of the full separation between Greek and Egyptian styles in royal portraits between Alexandria and the other Greek cities on the one hand and the other parts of Egypt on the other. In other words, the concept of Alexandria as having been a purely Hellenic city has been reconsidered if not changed.

Very indicative in this concern is the colossal statue which stands now in front of the new Bibliotheca Alexandrina (Fig. 2) ${ }^{20}$. This statue was part of a group of Ptolemaic royal couples which had once stood in front of the great Pharos lighthouse of Alexandria ${ }^{21}$. It rep-

\footnotetext{
${ }^{17}$ Some attributed this head to Ptolemy IV: BRECCIA, 1926: 59-60, no.12, 1. 26, 2; ADRIANI, 1938: 103; For its attribution to Ptolemy VI see: KYRIELEIS, 1975: 59-62, F2; KISS, 1976: 294; SMITH, 1988: 170, no. 72; GRIMM, 1998: 116-17, fig. 117 a-b; ASHTON, 2001a: 53-54, no. 19; ASHTON, 2001b: 88, no. 15; STANWICK, 2002: 107-108, no. B7.

${ }^{18}$ LAWRENCE, 1927: 67 ff.; BIEBER, 1961: 4; SCHLUMBERGER, 1970: passim; MARTIN et al., 1970: 339.

${ }^{19}$ The first was the expedition of the Centre d'études alexandrines (CeAlex) led by Jean-Yves Empereur who concentrated his efforts in the area around the citadel of Qaitbay, the coasts of the former Pharos Island. The second was that of the European Institute of Underwater Antiquities led by Frank Goddio who explored the Eastern harbour as well as the suburb towns of Canopos and Herakleion.

${ }^{20}$ Discovered in the 1990s by the expedition of the CeAlex, salvaged and restored by the same team in October 1995 . Erected in its current place in 2001.

${ }^{21}$ Of this group of Ptolemaic couples, a queen wearing the knotted garment of Isis and with a corkscrew hair style with a uraeus and diadem has been recovered earlier in the 1960s by the Egyptian scuba diver Kamel Abu El-Saadat. FROST, 1975: 126, fig. 1. It was incorrectly identified as Isis Pharia, until the new discoveries, which have salvaged the statue's Hathoric crown, proved that it is a Ptolemaic queen. Because of the eroded facial features, arguments for its dating and identification went the same as those for the Ptolemy of the Bibliotheca, some dated it to the early Ptolemaic Period: GRIMAL, 1996: 567; EMPEREUR, 1998a: 94; CORTIGGIANI, 1998: 39-40, fig. 10. Others dated it to the mid 2nd century B.C.: ASHTON, 2001a: 58, no. 24b; ASHTON, 2001b: 110, no. 56; STANWICK, 2002: 116, no. c27.
} 


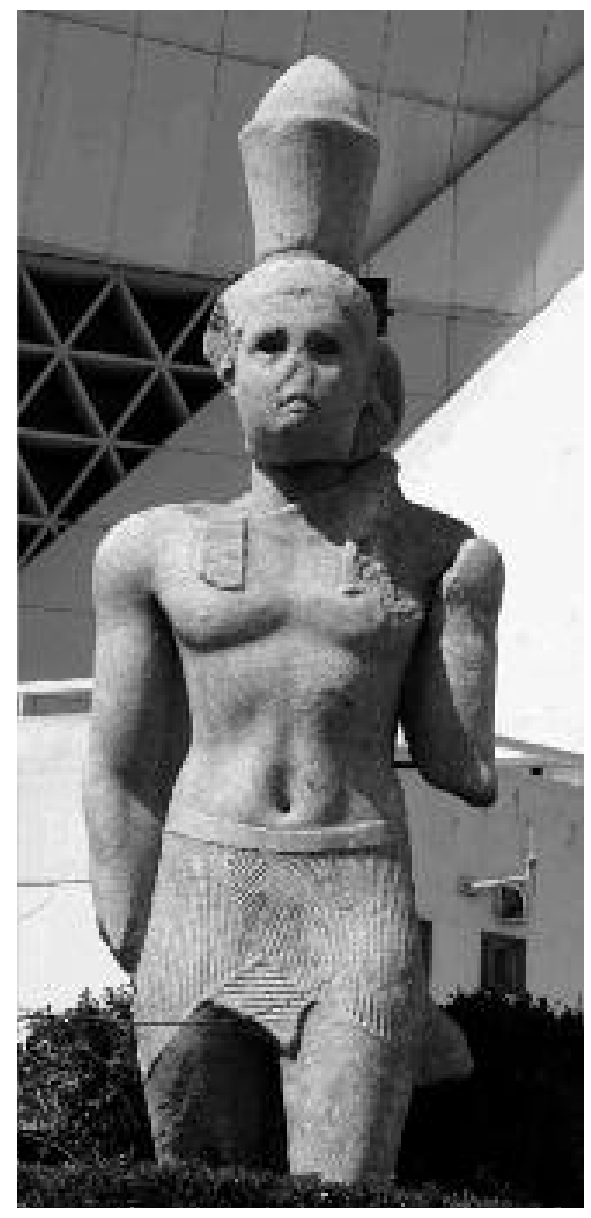

Fig. 2: Statue of Ptolemy II?, Alexandria (photo by the author).

resents a frontally standing Ptolemy with the left leg advanced in the conventional Egyptian style. He wears a ribbed nemes-headdress with the double crown and the shendyt. A mixture of Greek elements is clearly visible such as the royal diadem and the inlayed eyes (now missing) and a row of locks of hair which appear under the nemes. According to stylistic criteria, Empereur, the discoverer ${ }^{22}$, Grimal, Cortiggiani, Yoyotte and Kiss dated the statue back to the first half of the 3rd century ${ }^{23}$. Others dated it to the mid-2nd century ${ }^{24}$. Guimier-Sorbets emphasizes the earlier date for the statue according to her study of the base and its ornaments, she interprets it as a posthumous figure of Ptolemy I executed during the reign of Ptolemy II and erected there on the occasion of the deification of Soter and his queen Berenice as Theoi Soteroi $i^{25}$.

This statue together with others of the same group indicate clearly that the Ptolemies have chosen Egyptian material and style for their statues which were to be erected at the entrance of the great harbour of their capital. By this choice, they emphasized the idea that they are the successors of the Pharaohs, the legitimate rulers of a civilization that inspired the Greeks at their early beginnings. Choosing this particular location for their colossals meant that they were the patron deities for the city and its harbour, saviours of mariners and protectors of navigation, as one would infer from the inscription on the famous lighthouse of Alexandria ${ }^{26}$. Even though the concept of a protecting deity for the city and the harbour is a Greek one, the choice of the king and his queen to be those deities expresses an Egyptian direct cultural influence. For the Egyptians, the king is the founder and controller of stability and prosperity of the country. Worship has to be carried out in his name. The Egyptian

\footnotetext{
22 EMPEREUR, 1996: 967-968, figs. 4-6; EMPEREUR, 1998a: 76-77; EMPEREUR, 1998b: 103, 307, no. 64.

${ }^{23}$ GRIMAL, 1996: 568-570; CORTIGGIANI, 1998: 35-40, 103, fig. 9; YOYOTTE, 1998a: 204, no. 18; KISS, $1998: 173$.

${ }^{24}$ ASHTON, 2001a: 58, no. 24a; ASHTON, 2001b: 92, no. 20; STANWICK, 2002: 115=16, no. c22.

${ }^{25}$ GUIMIER-SORBETS, 2007: 163-176.

${ }^{26}$ FRASER, 1972: I, 18 ff.; II, notes 104-124.
} 
priests must support the throne on which seats the new Horus, the successor of Osiris. Ruler cult of the pharaohs was a principal part of the Egyptian religion, a phenomenon that had not been known in Greece or Macedon. It was natural then for such «cult» statues to appear in Egyptian attire which is not void from Greek elements that express the particularity of the Lagids as Hellenistic dynasts ruling a powerful kingdom.

One last example is very important in this concern, the basalt statue of Hor son of Hor, priest of Thoth during the late Ptolemaic Period (Fig. 3$)^{27}$. It is one of a series of male statuary type characterized by the fringed mantle which is usually worn over a sleeved tunic ${ }^{28}$. The statue is in the Egyptian conventional striding posture with the right hand sticking to the body and the other bent at the elbow and turned forward holding something in its clenched fists. The facial features seem to express the true features of the subject. The curved lines bordering the area between the nostrils, the mouth and the chin together with the receding curved hair boarders over the forehead express the serious and pensive moods which are characteristics of the veristic Alexandrian style. Inscriptions on the back pillar indicate Hor's priestly office ${ }^{29}$. The importance of this statue lies in

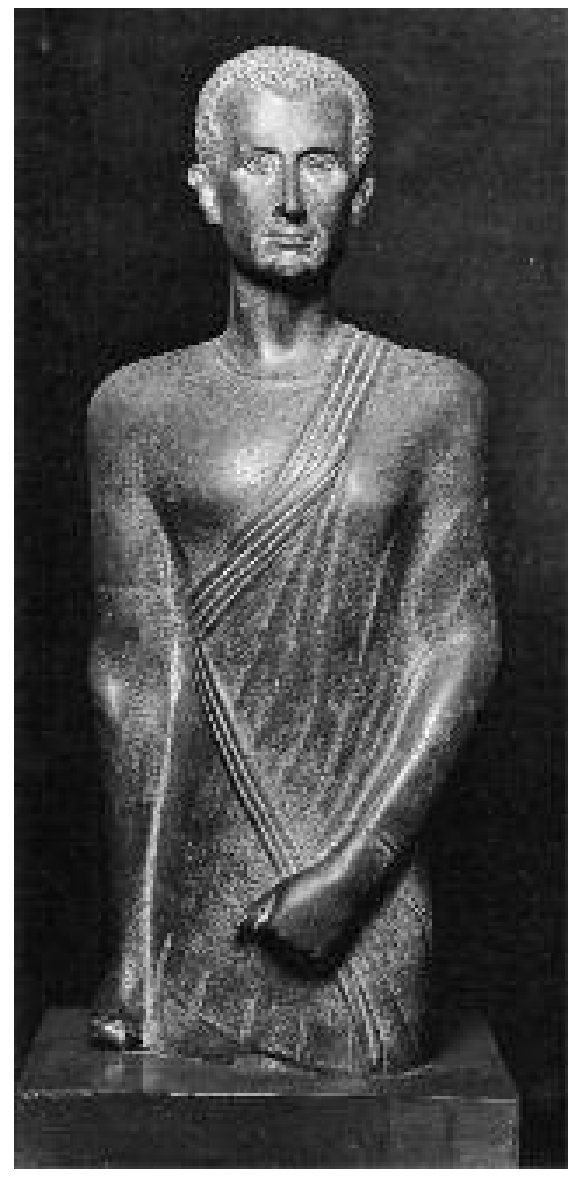

Fig. 3: Statue of Hor son of Hor, Cairo Egyptian Museum. its provenance at Kom El-Dikka in Alexandria. Recent excavations at the area proved that part of it was occupied by the Boubasteion ${ }^{30}$ which was an early Ptolemaic religious centre. Excavations of the Polish expedition in the vicinity of the Boubasteion indicate that during the Ptolemaic Period the area was a Greek residential district ${ }^{31}$. The importance of this area was gradually increasing to the extent that in late Roman times it became part of the city's centre ${ }^{32}$.

\footnotetext{
${ }^{27}$ Egytian Museum at Cairo, JE 38310, CG 697.

${ }^{28}$ For other examples in this series see: ASHTON, 2001a: 178-92, nos. 187, 189-91.

${ }^{29}$ BORCHHARDT, 1930: 39-40, pl. 128; GRAINDOR, 1939: 138, no. 74; BOTHMER, 1960: 170-73; GRIMM, JOHANNES, 1975: 19, no. 16; ASHTON, 2001a: 182-83, no. 190.

${ }^{30}$ See supra n. 2.

${ }^{31}$ KUBIAK, 1967: 47-80.

${ }^{32}$ MAJCHEREK, 2003: 25-34; MCKENZIE, 2003: 35-63.
} 
In the light of the great number of huge granite architectural elements which were located submerged in the area around the citadel of Qaitbay, former location of the Pharos lighthouse, and the discovery of early Ptolemaic mixed style sculptures not only royal portraits but also portraits of individuals, and the presence of some early Ptolemaic sculptures in the pure Egyptian style inside Alexandria in addition to some literary testimonies of the presence of Egyptian elements in the famous boat-palace of Ptolemy IV, Thalamegos ${ }^{33}$, one would tend to think of Ptolemaic Alexandria as a city that incorporated Egyptian and Greek traditions in both physical and cultural aspects of its life.

The strong Egyptian tradition and its prominent appearance in Ptolemaic arts was one of the reasons which led some scholars of the 19th century to believe that Alexandria, unlike the other Hellenistic centres, had not any opportunity to introduce its own artistic creations $^{34}$. During the 20th centuries, systematic rescue excavations at the city and its environs yielded plenty of plastic arts. Such works of art responded positively to Theodor Schreiber who was the first to speak of an Alexandrian school of art using the much disputed term of Pan-Alexandrianism ${ }^{35}$. Schreiber's concluded that Alexandria was the place of origin for many of the known Hellenistic artistic trends. Since then, the concept of the Alexandrian contribution to Hellenistic art was a subject of an endless series of discussions and disputations ${ }^{36}$.

There is no doubt that the Greek artists at Alexandria worked under the auspices of the kings to introduce arts on the official level according to the norms of fourth century masters. In the same mainstream of Hellenistic sculpture, Alexandrian sculptors had their own contributions; they managed to mix the Praxitelean softness and S-curved bodies with the Lysippan small heads and smart bodies in addition to the penetration into the personality of their subjects expressing particularly their pensive moods ${ }^{37}$. Two main features are attributed with considerable evidences to Alexandrian artists; Sfumato, which is a technique that makes the sculpted human face looks distant from the viewer as if there is a barrier of transparent smoke between them. Morbidezza is a feature complementing the $s f u$ mato, it is a way of rendering the surfaces so smoothly and tenderly with delicate features that give the viewer the feeling of high ranked personality with austere beauty. As an example of these two features, to mention but one, is the head of the most famous queen of Egypt, Cleopatra VII in Berlin ${ }^{38}$. The simple melon-coiffure, with some short curls border-

\footnotetext{
${ }^{33}$ Kallixeinos of Rhodes, Peri Alexandreias, Apud Athenaios, Deipnosophistae 5. 204-206. For a scholarly study and reconstruction see: PFROMMER, 1999: 93-124.

${ }^{34}$ BRUNN, 1889: vol. 1, 595; OVERBECK, 1882: vol. 2, 199; MITCHELL, 1883: 606.

${ }^{35}$ SCHREIBER, 1885: 380-400.

${ }^{36}$ For a detailed discussion of Schreiber's theory and the scholarly responses to it, see: STEWART, 1996: 231-246.

${ }^{37}$ ADRIANI, 1948: 14-19. Others see in these features a general Hellenistic trend that dominated the early 3rd century works, see: POLLITT, 1986: 250. About the supposed visit of Lysippos to Egypt and his relation to the early Alexandrian art, see: DÖRIG, 1995: 299-304.

${ }^{38}$ Staatliche Museen zu Berlin, Antikensammlung 1976.10.
} 
ing the forehead with the plain diadem are expressing the aristocratic unreachable simplicity. The very smooth turn of the head to the right with a far reaching look are all indications of an Alexandrian workshop ${ }^{39}$.

Hellenistic centres witnessed the diffusion of a new trend of plastic art that represented different types of ordinary persons who were not occupying any important posts or religious offices or any other social importance, they were, very simply, people from the street. These new representations are generally termed «genre figures». The term comprises figures of deformed people, drunken persons, aged men and women, simple workers like peasants and fishermen, slave children, and individuals with features of various different ethnic origins. This genre is generally supposed to have been used for decoration and secular purposes expressing daily life far from any religious context.

It is, again, Schreiber's initiative that the origin of genre figures must be ascribed to Alexandria, a theory which could partially be based upon the cosmopolitan nature of the Alexandrian society which could have its impact on representations of multiple ethnic groups which resided in the city ${ }^{40}$. Himmelmann, even though totally convinced with Alexandria as home of a new realistic tendency in Hellenistic arts, yet he sees that Hellenistic types were strongly affected by regional particularities in their socio-political context ${ }^{41}$. However, new approaches to the problem introduced some reasonable solutions for this problem.

Alexandrian terracotta and bronze figurines comprised a countless number of genre figures as well as few examples of marble monumental pieces. The latter is a category of sculptures of which certain types can be attributed, with a degree of certainty, to Alexandria. The marble statue of an old drunken woman in the Munich Glyptothek is one good example for the Alexandrian genre ${ }^{42}$. The statue is nearly 1 metre high representing a seated old woman. She wears a long and wide garment which is fastened with pins at the shoulders. The garment reminds us with the description of Theokritos (Idyll XV, The Women at the Adonis Festival) of the festivity dress of Praxinoa when she was preparing herself to attend the Adonis festival in Alexandria together with her friend Gorgo. The woman embraces by her two hands a large wine jug known as lagynos, while her head is raised up indicating her drunken mood. The text of Eratosthenes, quoted in Athenaios (Deipnosophistae, 276a) gives us a clue to the interpretation of this statue. It speaks about the festival known as the Lagynophoria, created by Ptolemy IV in honour of Arsinoe III. During this festival, people could come to the palace and sit on rush stools holding their own lag-

\footnotetext{
${ }^{39}$ FITTSCHEN, 1983: Pl. XXLX, nos. 5-6; SMITH, 1988: No. 68; BIANCHI, 1988: 187-88, no. 77; MORENO, 1994: 730; GRIMM, 1998: fig. 125.

${ }^{40}$ SCHREIBER, 1885: 380- 400.

${ }^{41}$ HIMMELMANN, 1983: 21.

${ }^{42}$ A Roman coy of a Hellenistic original datable to the third-second centuries B.C. Munich, Glyptothek, inv. 437, another copy of the same original is in Musei Capitolini, inv. MC 299/S.
} 


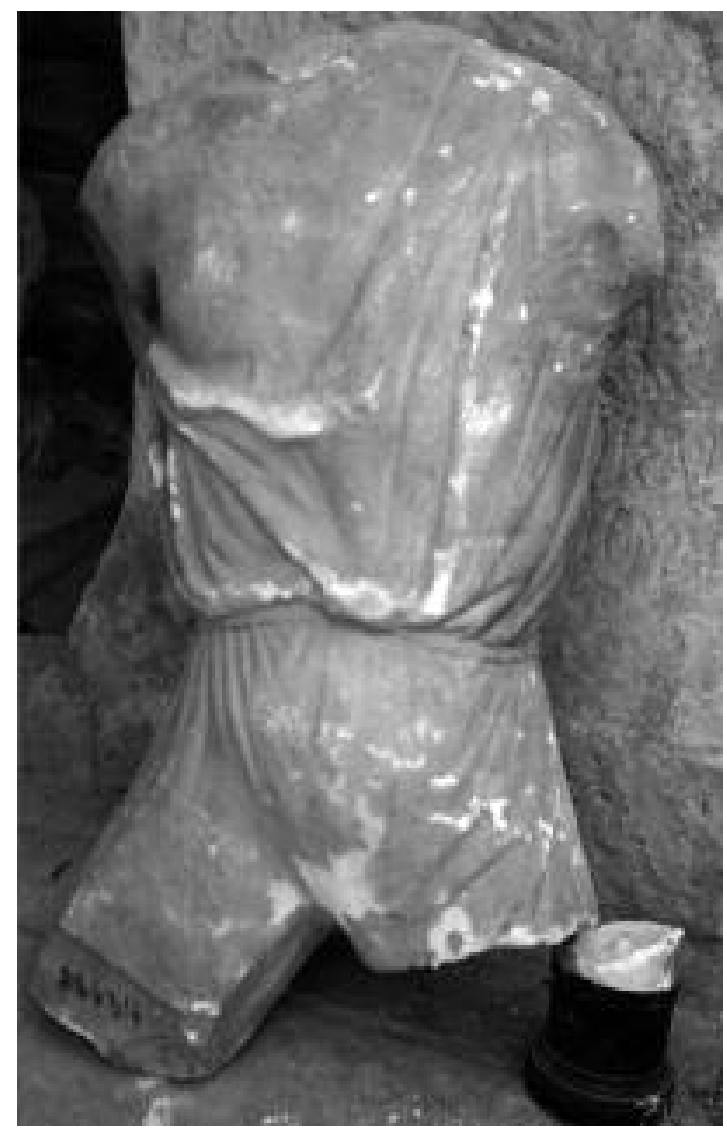

Fig. 4a: Statue of a farmer, Greco-Roman Museum of Alexandria (photo by S. Ashour).

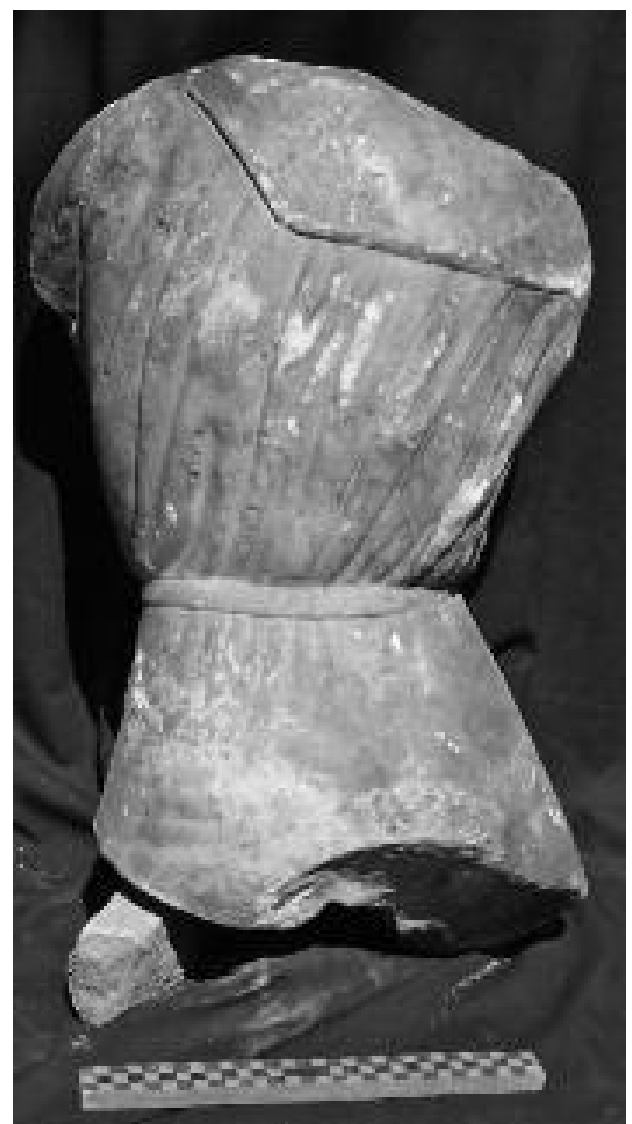

Fig. 4b: Back side of Fig. 4a (photo by S. Ashour).

ynoi and drink and eat as much as they $\mathrm{can}^{43}$. In the light of the previously mentioned literary texts, the Alexandrian origin of such a statue becomes unquestionable.

The Greco-Roman Museum of Alexandria possesses a number of stone sculptures representing different types of labourers and craftsmen which are closely related to our subject. A torso of a nearly life size marble statue depicts a man in a moving or working pose (Fig. $4 a)^{44}$. The upper part is muscled, strongly constructed in a leaning forward posture. The man is dressed in exomis which is a knee-length dress belted at the waist and fastened at the left shoulder leaving the right part of the chest exposed ${ }^{45}$. A wide piece of textile atop the

\footnotetext{
${ }^{43}$ POLLITT, 1986: 143, fig. 154.

${ }^{44}$ Inv. 26034. First published by: BONACASA, 1960: 170 ff.; ASHOUR, 2007: 745-46, no. 319.

${ }^{45}$ The exomis is well described in Theocritus' Idyll 21, where he describes a fisherman with strong muscles and an exomis covering his chest. It seems that this kind of garments was usually worn by labourers in Ptolemaic Egypt.
} 


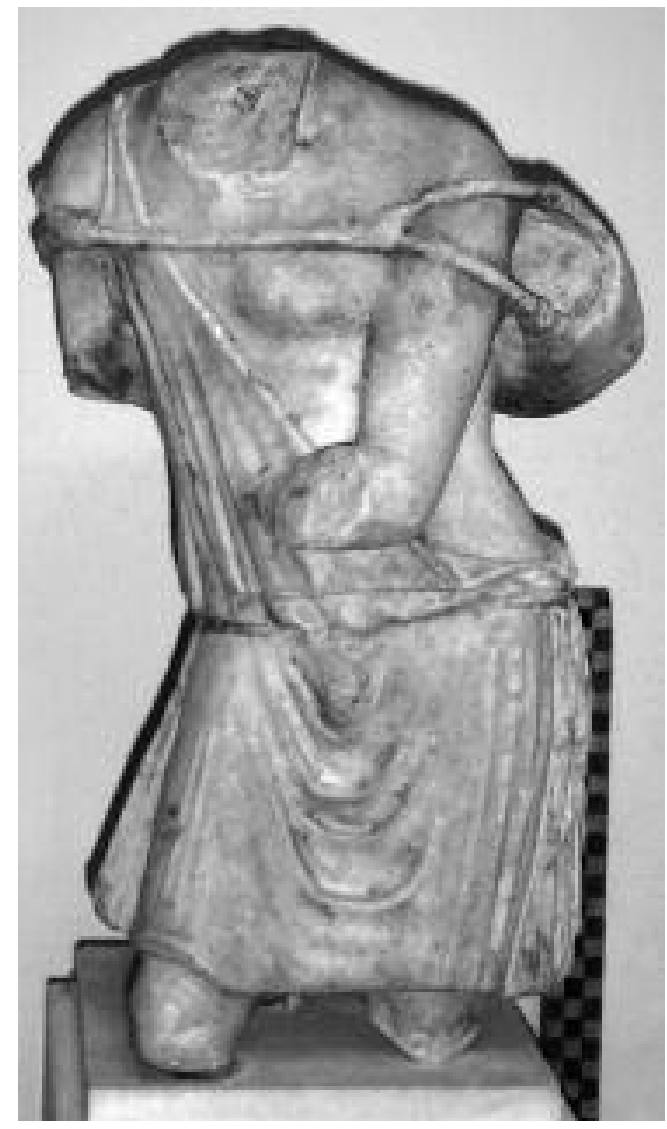

Fig. 5a: Statue of a farmer, Greco-Roman Museum of Alexandria (photo by S. Ashour).

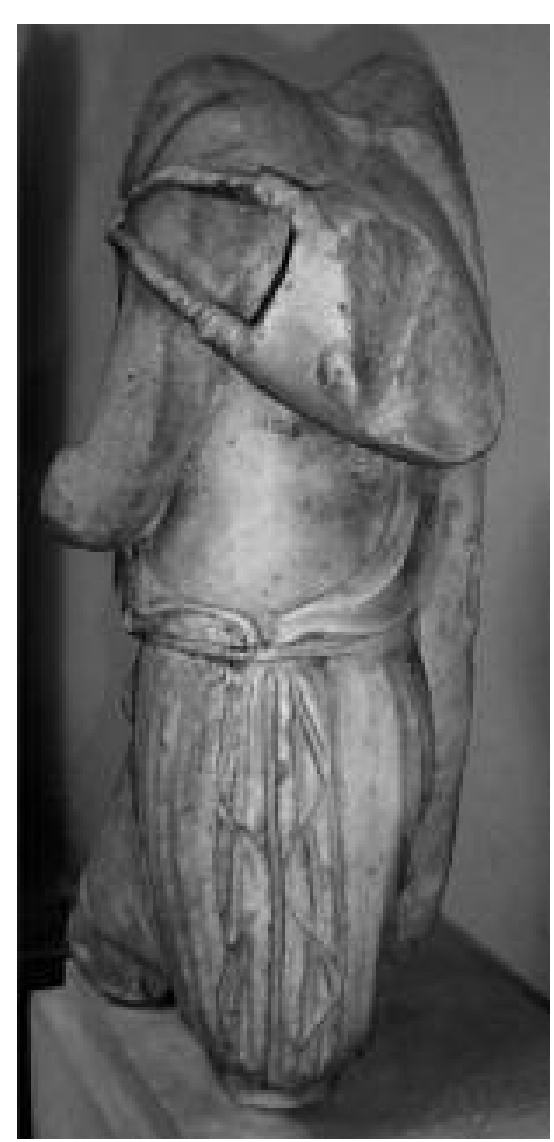

Fig. 5b: Left back side of Fig. 5a (photo by S. Ashour).

back (Fig. 4b) seems to have been a pad for a heavy load that the man was carrying. Of the same type of walking farmers usually carrying a load on their backs there is another example (Figs. 5a ${ }^{46}$; the statue wears the same exomis and carries a basket which is suspended with a thick rope across the chest (Fig. 5b). The movement is accentuated by the leaning of the body to the right, the open legs, and the rigid right knee. The muscled chest with protruding breasts is the same as Fig. 4 and is a naturalistic expression of hard labour. The publisher dates both statues, according to the style of drapery, to the late Hellenistic Period. In the absence of parallels, these two statues were compared to some similar representations in a statue of Odysseos from the Antikythera shipwreck ${ }^{47}$ and the most interesting Triptole-

\footnotetext{
${ }^{46}$ Inv. 23924, white marble. First published by: BONACASA, 1960: 170 ff.; ADRIANI, 1972: 141, no. 3, tav. $25,3$.

${ }^{47}$ RIDGEWAY, 2000: 59; 73, pl. 25; ASHOUR, 2007: 874, fig. 430.
} 


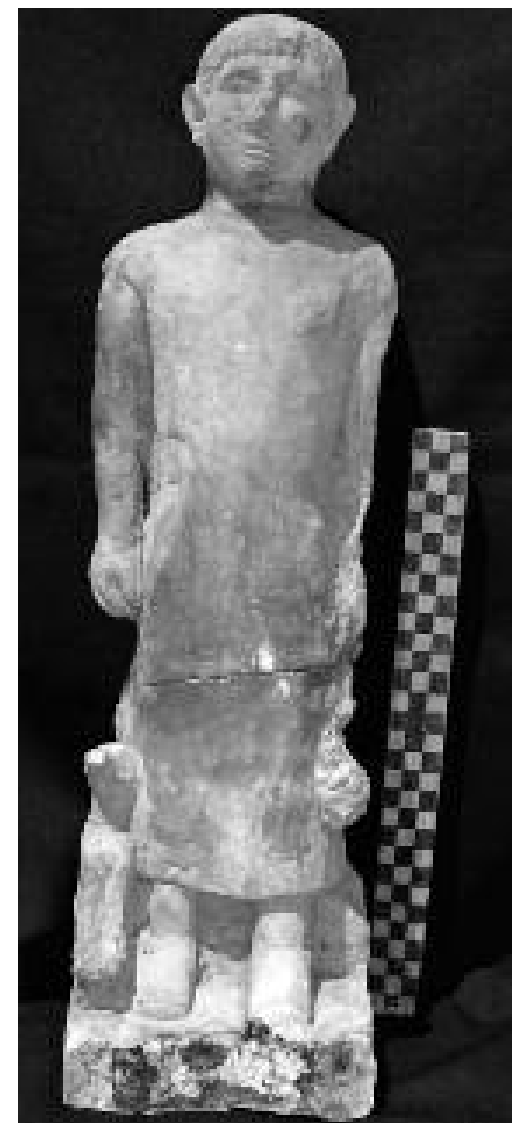

Fig. 6a: Statue of a shepherd, Port Saïd Museum (photo by S. Ashour).

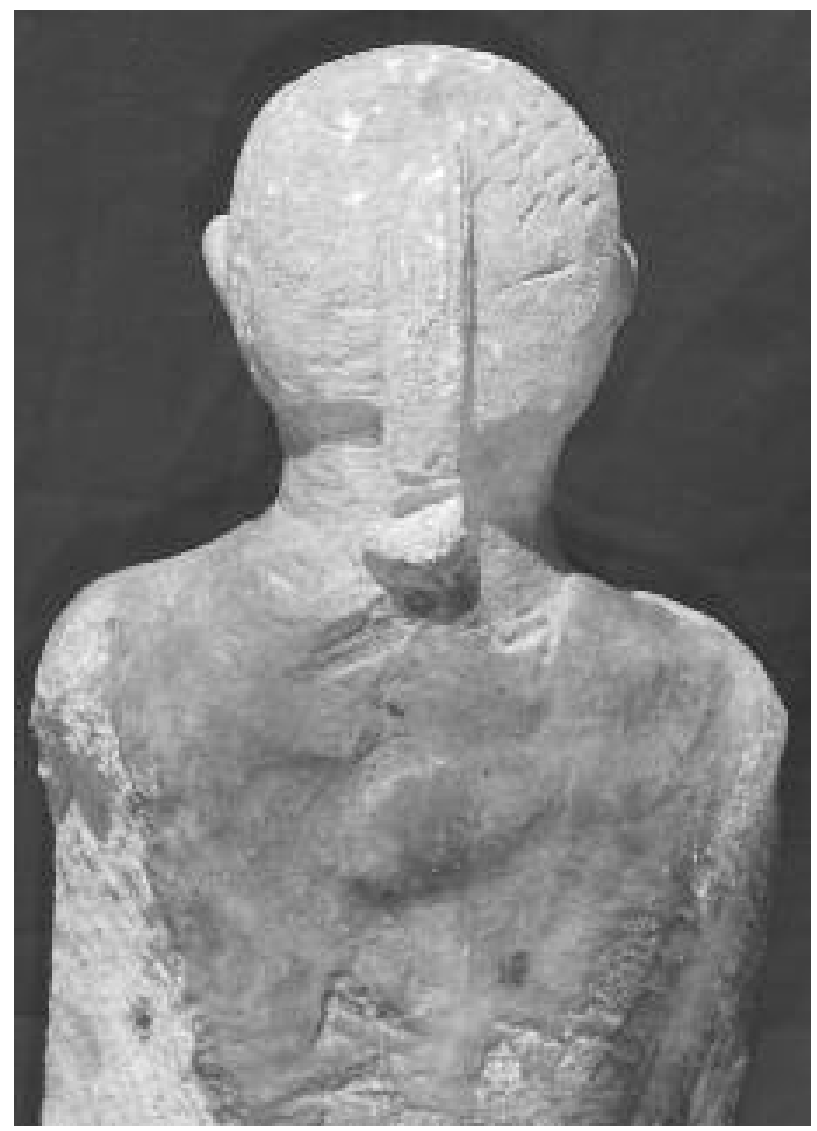

Fig. 6b: Head's back of Fig. 6a (photo by S. Ashour).

mos on the famous Tazza Farnese, Fig. $7^{48}$. Various other examples of men wearing the exomis and carrying baskets either on their backs or in hands were found in Egypt ${ }^{49}$. Publishers and other specialists assumed that the type is derived from an Alexandrian original dated to the early Ptolemaic Period with nothing serious to challenge their assumption ${ }^{50}$.

Yet, another statue of limestone represents a different unique type of male genre figures (Fig. 6a $)^{51}$. The man is rigidly standing with advanced left leg, a posture that reminds

\footnotetext{
${ }^{48}$ MORENO, 1994: II, 706-11. For arguments on the type see also Idem, I, 345-50, figs. 437-43.

${ }^{49}$ For a farmer in Faïence see: HIMMELMANN, 1980: taf. 20-23. Another in marble: LAUBSCHER, 1982: 110, no. 22c, taf. 16.2. For arguments on the type see also: MORENO, 1994: I, 345-50, figs. 437-43; II 706-11.

${ }^{50}$ For some replicas see: LAUBSCHER, 1982: 25, no. 23a taf. 17.1; BONACASA ,1960: tav. LII, LIII; ASHOUR, 2007: 832, 875, no. 404 .

${ }^{51}$ Port Said Museum, Inv. P. 31, formerly in the Greco-Roman Museum Inv. 23831. First published by: ASHOUR, 2007: 747$48 ; 875-76$, no. 320 .
} 
us with the Egyptian striding figures of dynastic times. This Egyptianizing attire is emphasized by the high protruding ears, the plain linear eyebrows, almond eyes and the obscure facial features without any definite expression. Another unique feature is the presence of a short support at the back of the head (Fig. 6b) which seems to be a reminiscent of the Egyptian conventional back-pillar. However, Egyptian features are mingled with Greek ones; the man wears, not the exomis, but a long sleeved tunic and short necked

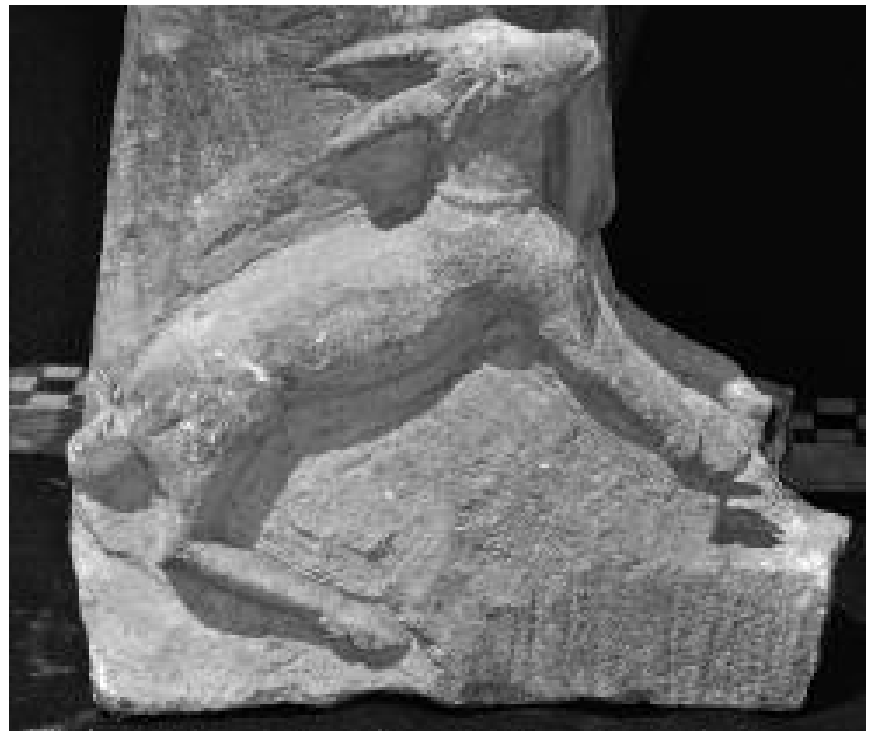

Fig. 6c: Goat at the right side of Fig. 6a (photo by S. Ashour). boots. He carries in his left hand a basket of fruits. The shape of the basket is different from common types usually depicted with farmers and fishermen. The man holds in his right hand a halter of a goat which appears at his right side jumping in a movement full of joy and vitality (Fig. 6c). The fore hides of the goat are bent and its head is raised up in a lively Greek style. The different shape of the basket and the presence of the goat make one thinks of a shepherd rather than a farmer. The publisher believes that the contrast between the static pose of the farmer and the dynamic movement of the goat is understandable if we look at the native dynastic prototypes on the one hand and the Hellenistic goat motive in other works of art on the other ${ }^{52}$.

However, the previously mentioned examples testify for the particularity of Alexandrian genre figures. The modification of some Egyptian prototypes into Hellenized forms sides for the Alexandrian origin of certain types ${ }^{53}$. They confirm the idea of the Egyptian

\footnotetext{
${ }^{52}$ Full comparative discussions and interpretations in: ASHOUR, 2007: 876.

${ }^{53}$ In his dissertation on representations of officials and craftsmen in Egypt during Ptolemaic and Roman times, Sobhy Ashour compares many of the genre sculptures in the round with the reliefs of the pronaos of the tomb of Petosiris where the earliest scenes of agriculture works, shepherds and vintage production appeared. The tomb is located in the cemetery of Hermopolis Magna known as Tuna Al-Gebel in Middle Egypt. Its date is still disputable but on grounds of stylistic analyses, the Naos reliefs are preferably dated to the late 5th century B.C. while the pronaos is believed to have been a 4 th century addition that took place during the early years of Ptolemaic presence in Egypt. What is completely evident about the reliefs of the pronaos is that they were executed by a team of sculptors including both Greek and Egyptian masters who introduced an amalgam of elements inspired by both traditions. ASHOUR, 2007: $834 \mathrm{ff}$.
} 
origin of representations of farmers, shepherds, fishermen and other workers who formed the core of the society and could have been seen in the streets of Alexandria and the Chora by artists living in the city and reading the poems of Theocritus.

One last masterpiece which sheds light on other universal horizons of Alexandrian art is to be discussed here, the Tazza Farnese (Fig. 7) ${ }^{54}$. It is a Sardonyx cameo carved on its exterior with an aegis decorated with the head of the Gorgon Medusa, a familiar decorative figure which appears very frequently on Greco-Roman utensils and works of art. The scene on the inside of the bowl depicts a bearded god sitting on a tree trunk holding a cornucopia in his left hand. At the lower centre, a female figure reclines on a sphinx wearing a dress characterized by the Isis knot between the breasts. In her upraised right hand she holds what seem to be sheaves of grain. In the centre of the scene, strides a beardless male figure with a seed bag hanged to his left wrist, and holds in his left hand an object which is interpreted as a plow. On the right side of the scene recline two female figures, the lower one holds a phiale in her left hand and the upper one rests her right hand on a cornucopia while

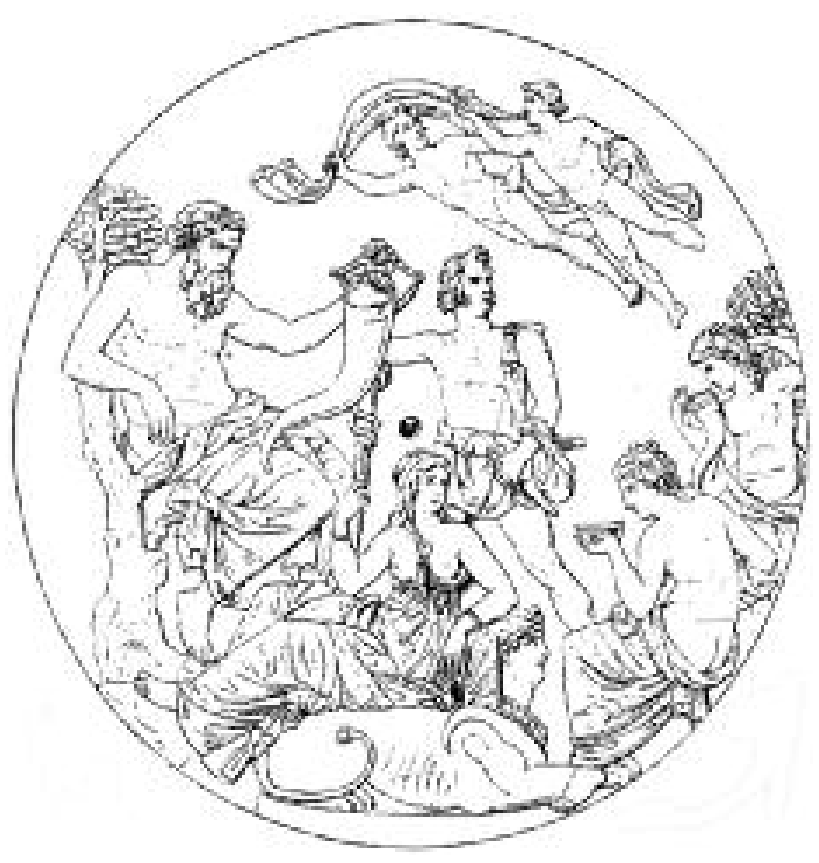

Fig. 7: Drawing of the interior scene of the Tazza Farnese, after Fürtwängler 1900: II, 256. Downloaded August 2011 from $<$ http://digit.ub.uni-heidelberg.de>. touching her hair with the left hand. At the top of the scene, two male figures fly across the sky, one holds a long piece of textile, most probably a mantle, which billows out over his head, while the other blows a horn or a shell.

Since its first publication, the Tazza Farnese became the subject of great controversies among scholars. Many and different interpretations for its iconography emerged: The publisher's interpretation of the main scene was that it represents the Egyptian triad of Osiris, Isis and Horus, and the female pair represents Ancherroe and Memphis, daughters of the Nile and personifications of its main branches, while the male pair represents Shu and Tefnut, the air and water. This interpretation has been revised and

\footnotetext{
${ }^{54}$ Museo Archeologico Nazionale di Napoli, inv. Mann, 27611. First published by: VISCONTI, 1790: III, 63-75, tav. C1.
} 
modified in 1900 by Fürtwängler ${ }^{55}$ who thought that the seated principal deity is the Nile and the female figure reclining on the sphinx is Euthenia, the personification of prosperity and abundance who was known as the consort of the Nile. As for the youth with the plow, Fürtwängler identified him as a combination of Horus and Triptolemus. In the Greek Eleusinian myths, Triptolemus was the youth selected by Demeter to be taught how to cultivate the land and was sent back to earth to transfer this knowledge to mankind. The maiden with the phiale personifies the flooding of the Nile, while her companion holding the cornucopia refers to agricultural abundance. For Merkelbach ${ }^{56}$, in spite of his historical interpretation for the main figures, the two female figures are Satet and Anuket, goddesses of the first cataract of the Nile. Nicole Dacos returned to Visconti's identification of the two female figures as Memphis and Anchirroe, daughters of Nilus and personifications of its principal branches ${ }^{57}$, while La Rocca identifies them as Herse (dew and moisture) and Arousa (cultivated fields) ${ }^{58}$. Bastet identified the old bearded man with Hades or HadesDionysus or Osiris-Sarapis, and saw the woman reclining on the sphinx as Isis-Demeter and the youth who strides between them as Triptolemus ${ }^{59}$. He emphasizes that the reclining female pair are the Horae, seasons, specifically the seasons of flood and growth, and that the two flying males are personifications of the Etesian Winds.

Royal insignia led some scholars to combine the divine character of the main personifications with some historical figures. Charbonneaux ${ }^{60}$, Bastet $^{61}$ and Merkelbach ${ }^{62}$ have proposed that the principal figures are portraits of Ptolemaic royalty. They convincingly argued that the Ptolemaic Dynasty tried to perpetuate the traditional concept of divine power bestowed upon them as heirs of the Pharaohs through such an amalgamation of Egyptian and Greek deities. Charbonneaux's identifications is Ptolemy VI as Horus, Cleopatra I as Isis and Ptolemy V as Osiris. Moreno detected resemblance with royal portraits of Cleoptatra III, her husband Ptolemy VIII and their son Ptolemy $\mathrm{X}^{63}$. Thompson sees the vessel to have been commissioned by Octavian in order to celebrate his triumph in Aktium in the twenties of the 1st century B.C. ${ }^{64}$ John Pollini has the same opinion as Thompson and identifies the main males as Saturnus and Gallus or Genius Galliarum ${ }^{65}$.

\footnotetext{
${ }^{55}$ FÜRTWÄNGLER, 1900: II, 253-56.

${ }^{56}$ MERKELBACH, 1973: 116-27.

${ }^{57}$ DACOS, 1973: 69-72.

${ }^{58}$ LA ROCCA, 1984: 95-100.

${ }^{59}$ BASTET, 1962: 1-24.

${ }^{60}$ CHARBONNEAUX, 1958: 85-103.

${ }^{61}$ BASTET, 1962: 1-24.

${ }^{62}$ MERKELBACH, 1973: 116-27.

${ }^{63}$ MORENO, 1994: II, 706-11.

64 THOMPSON, 1978: 119-20.

${ }^{65}$ POLLINI, 1992: 283-300.
} 
Another scope of interpretations for the scene of the Tazza Farnese was also investigated; Merkelbach was the first to attempt to read it as an astronomical allegory of the constellations related to the inundation of the Nile. Although he is of the idea that the figures represent certain Egyptian deities, he thinks that each of these deities represent a constellation in the celestial sphere. He sees all these constellations centered around one principal figure, Horus who represents Orion. Accordingly, Merkelbach argues that the scene of the Tazza is a visual expression of what Eratosthenes, in his poem «Hesiodus», had alluded to as an Interpratio Aegyptiaca of the myth of Orion ${ }^{66}$. The figures in the scene, according to this astronomical interpretation are Sothis for Visconti's Isis (the Greek Canis Major), Triptolemus for Visconti's Horus, (the Greek Orion), Shu and Tefnut for the Etesian Winds, the sphinx is Osiris for the Egyptian sphere and Eridanus for the Greek, the Memphis and Anchirroe of Visconti are Satis and Anuket in the Egyptian sphere and Hyades and Pleiades in the sphaera graeca. Finally, Nilus is Sarapis for the Egyptians and Leo for the Greeks. In spite of his interpretation for the figures as representing purely Egyptian deities, Merkelbach saw the connection with the Greek tradition in the symbolic number of 7 figures. The triad and the female and male pairs, as corresponding to the general patterns of the group of constellations that are arranged around Orion in the Greek astronomical sphere which is known to both Egyptians and Greeks and accords with the Egyptian astrological planetary Decans. It is worthy of mentioning that the Egyptians reckoned the seasons by the heliacal risings of 36 stars 10 by 10 days, hence were called the Decans. The inundation season begins with the rising of Sothis, the star of Isis and at the same time, Orion begins his annual rising ${ }^{67}$.

Dwyer agrees with the astrological interpretation of Merkelbach. He is of the opinion that the figure of Isis is similar to the iconography of the constellation of Virgo. He also attempted to associate the attributes which appear in the scene with the four physical elements in the Stoic cosmology, namely: fire (Leading wind $=\mathrm{Shu}$ ), air (following wind = Tephnut), earth (corn-field, rhyton) and water (bowl). Additionally, he sees that the scene is an allegory of creation according to the Hermetic tractate known as the Poimandres. The inundation of the Nile has been interpreted as a type or archetype of creation, corresponding to the creation of time, the planets, the elements and the human life. For him, the Tazza Farnese is not only an astrological map but also an illustration of certain philosophic texts $^{68}$.

All the previously mentioned interpretations relate the scene to an allegory of the Nile and fertility of the Egyptian soil, symbolized respectively by the seated principal figure, Isis or Euthenia and the sphinx. Certain emphasis has been put on the inundation of the Nile

\footnotetext{
${ }^{66}$ MERKELBACH, 1963: 469-526.

${ }^{67}$ PARKER, 1971: 15; VON BOMHARD, 2000: 137-45.

${ }^{68}$ DWYER, 1992: 255-82.
} 
and the season which brings it, the maiden with the phiale, as well as the winds that cause it, the Etesian Winds. The latter, in this respect, is more likely to be the summer monsoons as a more accurate identification for the two male figures flying from a north-easterly direction. The major difference between the Etesian and the Monsoons is that the first are the annual dry winds (Greek $\varepsilon \tau \eta \sigma \varepsilon \alpha$, derived from $\varepsilon \tau \eta \sigma i \varepsilon \varsigma$, annual; $\varepsilon \tau o \varsigma$, year) that blow during summer and are correlated with the summer monsoons. The Monsoons are the seasonal winds which blow from the Indian Ocean and the Arabian Sea bringing heavy rainfall to the area from which the Nile emerges.

Nearchus, the admiral of Alexander the Great, was the earliest geographer to observe that the summer raining winds cause the Indus to flood and suggested that the same winds are the cause of the Nile flood. In an article published in 2000, M. El-Abbadi asserts that the causes of the Nile flood were clearly known to the Egyptian priests as early as the 7th century B.C., while this remained a mystery for the Greeks until the time of the Indian expedition of Alexander the Great led by Nearchus about whose observations we are told by Arrian (Anabasis Alexandria: VIII, Indica, VI). Abbadi also refers to another companion and historian of Alexander, Callisthenes who said, according to Abbadi's translation: «the rising of the Nile resulted from rains in summer in the southernmost parts» ${ }^{69}$. The discovery of the Monsoons took place in the second half of the 2nd century B.C. by Alexandrian scientists $^{70}$.

Visconti dated the work to the Hellenistic Period and emphasized that Alexandria is its city of provenance. Other scholars who tended to interpret the scene as representing royal portraits tried to date the Tazza according to certain political and historical circumstances such as Thompson who dated the work at the twenties of the 1st century B.C. and related it to the Augustan Golden Age ${ }^{71}$. La Rocca dates it two decades earlier and suggests that only the figure of Isis is a portrait and should be identified as Cleopatra VII, who ordered the Tazza to be made in order to commemorate the victory of Marcus Antonius in 34 B.C. ${ }^{72}$. Charbonneaux identified the sphinx as Ptolemy V, the woman as Cleopatra I, and the youth as Ptolemy VI. Hence Charbonneaux's dating is between the death of Epiphanes 180 B.C. and that of Cleopatra I in 176 B.C. ${ }^{73}$.

Bastet was the first to try to date the Tazza on stylistic basis. He started with the Medusa carved on the exterior and dated it to ca. 100 B.C. due to the baroque appearance of the Gorgon's hair and the pathetic expression which have parallels of the same date ${ }^{74}$. Some other features on the tondo scene such as the folds of the Hymation of Nilus and the

\footnotetext{
${ }^{69}$ ABBADI, 2000: 53-58.

${ }^{70}$ See this volume: ABBADI - Alexandria's Revolutionary Role in North-South Navigation and Trade.

${ }^{71}$ THOMPSON, 1978: 112-22.

${ }^{72}$ LA ROCCA, 1984: 95-100.

${ }^{73}$ CHARBONNEAUX, 1958: 85-103.

${ }^{74}$ BASTET, 1962: 1-24.
} 
body structure of the monsoons point to this date. If this date is correct and if we accept the idea of interpreting the figures as portraits of the Ptolemaic family in the guise of gods, the author of this article is inclined to support the identification of Moreno who sees them as Ptolemy VIII (died in 116), Cleopatra III and their son Ptolemy X who ruled jointly with his mother after 107 B.C. ${ }^{75}$. In this respect, some attention should be paid to the style of Horus/Triptolemus. The youth has a moustache, according to the extant repertoire of royal Ptolemaic portraits; it was not until the reign of Ptolemy X that the kings were represented with moustaches. The corkscrew hair style of the queen is typical of a late 2nd century date. Portraits of Cleopatra III are distinguished by locks of hair at the sides which are always shorter than the rest of her hair. It is Cleopatra III who was often represented as Isis-Demeter holding a cornucopia, or/and sheaves of grain and wearing a dress with the Isis knot. The nude breasts of both the queen and the seasons are characteristic of the late second and early first centuries B.C.

Although there has been much debate as to the Tazza Farnese's date and to the interpretation of its iconography, almost all scholars have assumed that it was a product of a skillful gem carver in the Ptolemaic court ${ }^{76}$. This artist must have been quite aware of what is going on in the halls and galleries of the Musem and the Library. It may not be far fetching if we assume that this masterpiece was made in celebration of the discovery of the Monssons, noted above, which apparently took place during the reign of Ptolemy VIII. Such an important discovery might have motivated the artist to celebrate and express the newly completed global vision, based on scientific basis, of the fertility of the Egyptian soil. The summer monsoons (the flying male pair) regularly cause the Nile (the seated king in the attire of the Nile) to flood. The flood season is followed by the harvest (the female pair) when people enjoy its fruits (the reclining queen in the attire of Isis-Demeter) after a hard labor in cultivating the land (sphinx) using the skills they were taught by the gods (Triptolemos $)^{77}$. Such a message would never be understood or appreciated in a normal level of audience, but only the well educated class who possesses a taste of intellectuality and an ability to discuss and interpret the syncretistic nature of the figures and the sophisticated expressions that lie in the composition of the scene in such precious a work of art. On the other hand, Alexandrian artists of the court recognized that their products should convene with this scientific and cultural milieu and become a medium for expressing the Alexandrian supremacy and scholarship.

\footnotetext{
${ }^{75}$ MORENO, 1994: II, 706-11.

${ }^{76}$ POLLITT, 1986: 259.

${ }^{77}$ In the repertoire of Harpocrates' iconography, not a single example, to my knowledge, is attested for a combination with Triptolemos. Moreover, Harpocrates had never been represented with moustache. Accordingly, the figure in the Tazza Farnese must be interpreted as Triptolemos. This interpretation seems suitable if we take into consideration that the reclining queen carries the grain sheaves which are direct attributes of Demeter as well as the cornucopia carried by the seated figure, Nilus.
} 